\title{
Residual circulation and thermohaline distribution of the Ría de Vigo: a 3-D hydrodynamical model**
}

\author{
S. TORRES LÓPEZ ${ }^{1}$, R.A. VARELA ${ }^{1}$ and E. DELHEZ ${ }^{2}$ \\ ${ }^{1}$ GOFUVI, Facultad de Ciencias, Universidade de Vigo, Campus de Lagoas-Marcosende, 36200 Vigo, Spain. \\ ${ }^{2}$ G.H.E.R., University of Liège, B5 Sart Tilman, 4000 Liège, Belgium.
}

\begin{abstract}
SUMMARY: A three-dimensional, non-linear, baroclinic model is described and tested for the first time to study the residual circulation and the thermohaline distribution of the Ría de Vigo (NW Spain) at short time scales and under different wind stress regimes. Two markedly different realistic scenarios were chosen: northerly upwelling-favourable winds and southerly downwelling-favourable winds. The numerical experiments carried out indicate that the hydrodynamic regime of the Ría de Vigo is mostly a consequence of wind events. As could be expected, moderately strong North winds reinforce the normal (positive) Ría circulation, while winds blowing from the South, when sufficiently strong, reverse the typical circulation pattern and reduce the characteristic outgoing velocities and the flushing time inside the Ría. The temperature and salinity fields generated by the model in both situations were compared with observations and found to be in qualitatively good agreement, supporting the 3D velocity field distribution.
\end{abstract}

Key words: numerical models, ría de Vigo, upwelling-downwelling, thermohaline distributions, currents.

\section{INTRODUCTION}

The coast of Galicia (NW Spain) is characterised by the presence of several embayments, usually called "Rías". Significant human settlements are associated with these embayments, which are also among the most important mussel culture areas of the world. In particular, the Ría de Vigo, located near the boundary between Portugal and Spain between $\left(42^{\circ}\right.$ $\left.09^{\prime} \mathrm{N}, 8^{\circ} 36^{\prime} \mathrm{W}\right)$ and $\left(42^{\circ} 21^{\prime} \mathrm{N}, 8^{\circ} 54^{\prime} \mathrm{W}\right)$ supports the highest population among the Rías (more than $500,000)$ and is probably the best known of all of them from an oceanographic point of view (Fig. 1).

The Ría de Vigo freshwater input comes from the Verdugo-Oitabén river (about 79\% of the total annu-

\footnotetext{
*Received October 4, 1999. Accepted June 20, 2000.
}

al mean freshwater flow to the Ría, López-Jurado, $1985)$, from the Lagares river ( 19\%, Alejo, 1994) and also partially from the city of Vigo (about $2 \%$, c.f. Fraga, 1996). The volume of freshwater flowing into the Ría is small (the total volume of freshwater present in the Ría represents only 2\% (Fraga, 1996) of the total volume of the Ría) and much smaller than the water exchanged with the shelf and the ocean. It will be shown, however, to have a non-negligible influence on the residual flow in the Ría.

The local winds, generally blowing along the axis of the Ría (because of the particular orography), can enhance or reduce the water flushing time (between 5 and 7 days) inside the Ría. The mixing between surface waters (highly dependent on local meteorological conditions) and the presence of North Atlantic Central Water (NACW), determines 


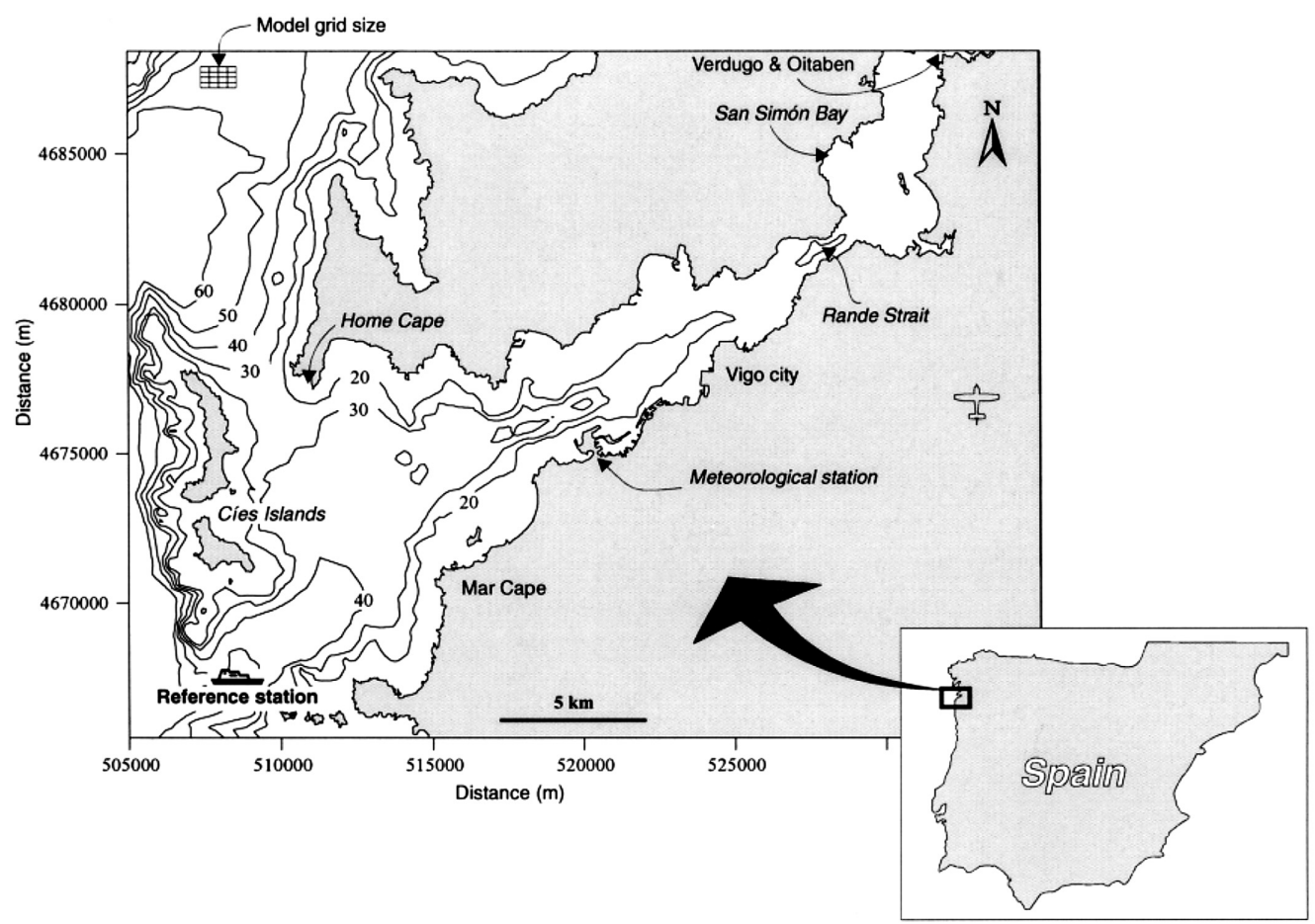

FIG. 1. - Map of the Ría de Vigo (NW Spain), with the location of the meteorological station, the reference station where boundary conditions profiles were measured and a scale grid. Contour lines represent depth in meters.

the characteristics of the oceanic waters flowing into the Ría.

The synoptic-scale meteorological field on the Galician shelf is dominated by upwellingfavourable winds (north, northwest direction) from early spring to the end of the summer. This seasonal wind field is, however, intermittently altered by relaxation or downwelling-favourable winds (south, southwest direction). Transitions between upwelling and downwelling-favourable winds tend to occur by September and October (Blanton et al., 1984; Bakun and Nelson, 1991, Castro et al., 1994). Although several studies describe the strong influence of the wind variability on the water mass dynamics in the Rías Baixas (Tilstone et al., 1994; Rosón et al., 1995; Doval et al., 1997; Rosón et al., 1997), no hydrodynamic 3-D model has yet been applied to study these influences.

Margalef and Andreu (1958) first estimated vertical velocities in the Ría de Vigo, giving mean annual values in the order of a few (1-2) metres per day. Later, using different box models, Prego (1988), Prego and Fraga (1992) and Ríos et al. (1992) calculated the horizontal residual velocities and the vertical associated mixing for a one-year period. Prego (1988), who divided the Ría into 5 horizontal sections of 2 vertical boxes, each separated by the halocline/pycnocline, obtained horizontal residual velocities (for a given date) ranging from $0.05 \mathrm{~m} \mathrm{~s}^{-1}$ near the Verdugo-Oitabén River to about $0.01 \mathrm{~m} \mathrm{~s}^{-1}$ next to the oceanic border.

Nogueira et al. (1997a; 1997b; 1998) used a statistical approach to model the hydrography of the Ría de Vigo using historical data collected from 1987 on a fortnightly basis, at a fixed station located in its central part. The temporal evolution of the thermohaline properties, nutrients and chlorophyll $a$ were fitted to a linear stochastic model. The results were used to describe the dynamics of the system, its seasonal patterns and its long-term trends. It was shown that, when helped by appropriate meteorological data, Box-Jenkins Transfer Function models adequately describe the dynamics of the Ría de Vigo ecosystem and may be useful as a first approximation to developing more sophisticated deterministic models.

Further developments in the modelling of the Ría de Vigo were made by Taboada et al. (1998), who developed a 3-D baroclinic model to study the seasonal variations of the Ría de Vigo's residual circulation. Their model used a very rough turbulence closure scheme (i.e. constant and uniform eddy diffusion and eddy viscosity coefficients), taking a constant horizontal grid spacing and eight vertical layers with a double- $\sigma$ vertical coordinate system. Since the authors developed the model with long-term analysis 
in mind, the wind stress was argued to be zero. This circulation model was compared to and found to be in reasonable agreement (order of magnitude) with the box model of Prego and Fraga (1992).

Very recently, Gómez-Gesteira et al. (1999) used the model of Taboada et al. (1998) in a 2D (i.e. vertically averaged) mode to track the dispersion of passive pollutants in the Rías of Vigo and La Coruña. They compared the residence time of particles within both harbours, concluding that the Ría de Vigo has a smaller residence time, probably due to the interference of a dock in La Coruña harbour.

The objective of this paper is to describe a full baroclinic 3D-circulation model of the Ría de Vigo that overcomes the limitations of earlier model attempts. The proposed model has a refined turbulence closure scheme and could be easily coupled to biogeochemical modules. It is used to evaluate the general influence of the meteorological forcing on the hydrodynamic conditions in the Ría de Vigo. Even when the model uses the main harmonic tidal components to simulate the tide inside the Ría de Vigo, no special tidal current analysis is included in this paper in order to focus on the residual circulation, which is mainly settled by wind forcing.

To achieve this goal, two groups of model simulations were carried out, one in typical upwelling conditions and one with downwelling-favourable winds. The model results were compared with similar situations already observed and described in many papers on the Rías Baixas, focusing on the mean general circulation patterns under different wind conditions instead of on any specific, datedependent event.

\section{MATHEMATICAL AND NUMERICAL MODEL DESCRIPTION}

\section{Mathematical aspects}

The hydrodynamic model is a modified version of the general purpose GHER 3D turbulent closure model previously applied to a wide variety of regions including the North Sea (Delhez and Martin, 1992), the Mediterranean Sea (Beckers, 1991), the Bering Sea (Nihoul et al., 1989) and the Black Sea (Grégoire et al., 1998). This is the first time that has been applied to a coastal estuarine domain.

The model relies on the well-known equation of the "weather of the sea" with the Boussinesq approximation (Eqs. 1 and 2, Table 1,2). Vertical turbulent fluxes are computed using a simple but robust and efficient closure scheme (Delhez et al., 1999) based on the well-accepted evolution equation for the turbulent kinetic energy, $k$ (per unit mass) (Eq. 4, Table 1, 2) and a parametric expression of the mixing length $l(\mathrm{~m})$ introduced by Nihoul (1984) (Eq. 4.3, Table 1, 2), which gives heed to the stratification and the surface wave activity.

This closure scheme has the advantage that it takes into account the advection, the diffusion, the local production-destruction and the history of turbulence through the evolution equation for $k$. Moreover, empirical sound velocities formulas are available for $l$ in shallow shelf seas so that the resolution of a differential equation for the dissipation rate of $k$ $(\varepsilon)$ can be avoided and replaced by an algebraic expression of the mixing length (Nihoul, 1984) (Eq. 4.3, Table 1,2). At the bottom, this expression respects the well-established asymptotic boundary layer. At the surface, eddies must be smaller in negligible wind conditions than when the wind buffets the surface. Therefore, the parameter $\delta \in(0.5,1)$ is introduced to adjust the mixing length profile to wind-mixed layer conditions. When a significant wind is blowing over the surface, the mixing-length at the surface must increase to reflect larger surface oscillations than expected. Thus, a smaller value of $\delta$ is used, (Martin and Delhez, 1994).

Stratification inhibits vertical motions and turbulent exchanges. Therefore, to model such a process, the mixing length is reduced according to the intensity of the stratification, measured by the flux Richardson number $\left(R_{f}\right)$, (Eq. 4.4, Table 1, 2). The values of $\varepsilon$ and $\tilde{v}$ are then obtained using simple dimensional arguments from the basic variables of the turbulence scheme (Eqs. 4.2 and 4.5, Table $1,2)$. Turbulent diffusivities for scalar quantities are supposed to be proportional to the turbulent viscosity according to the Reynolds analogy (Eq. 4.6). These coefficients are also a function of $R_{f}$ because the momentum exchange, involving pressure forces, is likely to maintain its efficiency at high Richardson numbers, whereas the transfer of the scalar quantities (temperature, $T$, Salinity, $S$ and buoyancy, $b$ ) is reduced as stratification increases (Nihoul et al., 1989).

\section{Numerical aspects}

The numerical model is based on a finite volume approach using the Arakawa C-grid (Arakawa and Lamb, 1977). For most of the terms in the equations, 
TABLE 1. - Mathematical model of the general circulation.

Continuity equation

$$
\nabla_{H} \mathbf{u}+\frac{\partial w}{\partial z}=0
$$

Momentum equation

$$
\begin{aligned}
& \frac{\partial \mathbf{u}}{\partial t}+\mathbf{u} \nabla_{H} \mathbf{u}+\omega \frac{\partial \mathbf{u}}{\partial \mathbf{z}}+f \mathbf{e}_{3} \wedge \mathbf{u}= \\
& =-\nabla_{H} q+\frac{\partial}{\partial z}\left(\tilde{v} \frac{\partial \mathbf{u}}{\partial \mathbf{z}}\right)+K_{H} \nabla_{H}^{2} \mathbf{u} \\
& f=2 \Omega \sin \text { (lat) } \\
& q=\frac{p}{\rho_{0}}+g z \\
& \frac{\partial q}{\partial z}=b(T, S)=-g \frac{\rho-\rho_{0}}{\rho_{0}}
\end{aligned}
$$

Equations for scalar constituents and properties temperature and salinity:

$$
\begin{aligned}
& \frac{\partial T}{\partial t}+\mathbf{u} \cdot \nabla_{H} T+\frac{\partial}{\partial z}(w T)=\frac{\partial}{\partial z}\left(\tilde{\lambda} \frac{\partial T}{\partial z}\right)+K_{H}^{s} \nabla_{H}^{2} T \\
& \frac{\partial S}{\partial t}+\mathbf{u} \cdot \nabla_{H} S+\frac{\partial}{\partial z}(w S)=\frac{\partial}{\partial z}\left(\tilde{\lambda} \frac{\partial S}{\partial z}\right)+K_{H}^{S} \nabla_{H}^{2} S
\end{aligned}
$$

Turbulent closure

$$
\begin{aligned}
& \frac{\partial k}{\partial t}+\mathbf{u} \cdot \nabla_{H} k+\frac{\partial}{\partial z}(w k)=Q^{k}+\frac{\partial}{\partial z}\left(\tilde{\lambda}^{k} \frac{\partial k}{\partial z}\right) \\
& Q^{k}=\tilde{v}\left|\frac{\partial \mathbf{u}}{\partial z}\right|^{2}-\tilde{\lambda}^{b} \frac{\partial b}{\partial z}-\varepsilon=\tilde{v}\left|\frac{\partial \mathbf{u}}{\partial z}\right|^{2}\left(1-R_{f}\right)-\varepsilon \\
& \varepsilon=\frac{\alpha^{2} k^{3 / 2}}{\ell} \\
& \ell=\kappa(z+h)\left(1-\delta \frac{z+h}{\zeta+h}\right)\left(1-\frac{R_{f}}{R_{f c}}\right) \\
& R_{f}=\frac{\tilde{\lambda}^{b} \frac{\partial b}{\partial z}}{\tilde{v}\left|\frac{\partial \mathbf{u}}{\partial z}\right|^{2}} \\
& \tilde{v}=\alpha l \sqrt{k} \\
& \tilde{\lambda}^{T}=\tilde{\lambda}^{S}=\tilde{\lambda}^{b}=\gamma \sqrt{1-\frac{R_{f}}{R_{f c}}} \tilde{v} ; \quad \tilde{\lambda}^{k}=\tilde{v}
\end{aligned}
$$

\begin{tabular}{|c|c|}
\hline$t$ & Time (s) \\
\hline$z$ & $\begin{array}{l}\text { Vertical coordinate above the reference level of the } \\
\text { free-surface }(m)\end{array}$ \\
\hline$h$ & Unperturbed depth (m) \\
\hline$\xi$ & Free-surface elevation $(\mathrm{m})$ \\
\hline$H=h+\xi$ & Total depth (m) \\
\hline$\sigma$ & Normalised vertical coordinate \\
\hline $\mathbf{v}$ & Three-dimensional velocity vector $\left(\mathrm{m} \mathrm{s}^{-1}\right)$ \\
\hline $\mathbf{u}$ & Horizontal current $\left(\mathrm{m} \mathrm{s}^{-1}\right)$ \\
\hline$\nabla_{H}$ & Horizontal differential operator \\
\hline$e_{3}^{H}$ & Unit vertical vector pointing upwards \\
\hline$f^{3}$ & Latitude dependent Coriolis parameter $\left(\mathrm{S}^{-1}\right)$ \\
\hline$K_{H}, K_{H}^{S}, K_{H}^{T}$ & $\begin{array}{l}\text { Horizontal diffusion coefficients for momentum, } \\
\text { salinity and temperature }\left(\mathrm{m}^{2} \mathrm{~s}^{-1}\right)\end{array}$ \\
\hline$g$ & Vertical acceleration of gravity $\left(\mathrm{m} \mathrm{s}^{-2}\right)$ \\
\hline$\rho, \rho_{0}$ & $\begin{array}{l}\text { Density of sea water and the reference value of the } \\
\text { density }\left(\mathrm{kg} \mathrm{m}^{-3}\right)\end{array}$ \\
\hline$b(T, S)$ & Buoyancy $\left(\mathrm{m} \mathrm{s}^{-2}\right)$ \\
\hline$T$ & Temperature $\left({ }^{\circ} \mathrm{C}\right)$ \\
\hline$S$ & Salinity \\
\hline$k$ & $\begin{array}{l}\text { Turbulent kinetic energy per unit mass (associated } \\
\text { with all sub-mesoscale processes) }\left(\mathrm{m}^{2} \mathrm{~s}^{-2}\right)\end{array}$ \\
\hline$\varepsilon$ & Dissipation rate of $k\left(\mathrm{~m}^{2} \mathrm{~s}^{-3}\right)$ \\
\hline$Q$ & Macroscale production-destruction of turbulence \\
\hline$\ell$ & Mixing length (m) \\
\hline$R_{f}$ & Macroscale Richardson flux number \\
\hline$\tilde{v}$ & Turbulent viscosity $\left(\mathrm{m}^{2} \mathrm{~s}^{-1}\right)$ \\
\hline & Turbulent diffusivity of buoyancy $\left(\mathrm{m}^{2} \mathrm{~s}^{-1}\right)$ \\
\hline$\tilde{\lambda} T, \tilde{\lambda} s, \lambda$ & $\begin{array}{l}\text { Turbulent diffusivity of temperature, salinity and } \\
\text { turbulent kinetic energy }\left(\mathrm{m}^{2} \mathrm{~s}^{-1}\right)\end{array}$ \\
\hline$\alpha, \delta, \gamma, \kappa, R_{f_{c}}$ & Model parameters \\
\hline
\end{tabular}

the horizontal discretisation is centred in space. The advection terms of momentum, salinity and temperature are represented by means of a hybrid scheme in which the level of upwind is controlled locally according to the estimated curvature of the field (Delhez and Martin, 1992; James, 1986).
TABLE 2. - List of symbols used in Table 1.

The time stepping uses the mode splitting technique (e.g. Delhez and Martin, 1992) according to which the depth-integrated continuity and momentum equations are first solved with a small time step, allowing for a good representation of the dynamics of the fast-moving surface gravity waves, and then a larger time step is used to solve the full set of 3D equations in which the barotropic component of the pressure gradient (i.e. the sea surface slope) is taken from the solution of the depth-integrated mode. For the depth-integrated equations, the external mode, an ADI scheme is used (Beckers and Neves, 1985). For the $3 \mathrm{D}$ equations, the internal mode, the discretization is explicit except for the vertical advection and diffusion terms that are taken implicitly for stability reasons (Beckers and Deleersnijder, 1993). As a result, a time step of $15 \mathrm{~s}$ is used to solve the external node without any significant phase error while the (more demanding) internal dynamics is addressed with a time step of $150 \mathrm{~s}$ according to the CFL condition.

The code also includes a new "drying and wetting" algorithm to cope with the possible drying of sandbanks at low tide. This algorithm is implemented in the solution of the external model. A grid cell is simply removed from the computational domain when the water height decreases below a given threshold (Hdry, 
TABLE 3. - Values of the hydrodynamic parameters in the numerical model

\begin{tabular}{ll}
\hline Hydrodynamic parameter & Numerical value \\
\hline Time step. T2D, T3D. & $15 \mathrm{~s}, 150 \mathrm{~s}$ \\
Horizontal viscosity. & $100 \mathrm{~m}^{2} \mathrm{~s}^{-1}$ \\
Horizontal diffusivity of temperature and salinity. & $10 \mathrm{~m}^{2} \mathrm{~s}^{-1}$ \\
Horizontal diffusivity of turbulent kinetic energy & $100 \mathrm{~m}^{2} \mathrm{~s}^{-1}$ \\
& \\
Turbulent closure parameters & \\
$\alpha$ & 0.5 \\
$\gamma$ & 1.1 \\
$\kappa$ (Von Karman constant) & 0.4 \\
$\delta$ (strong wind conditions) & 0.5 \\
Roughness length $z_{0}$ & $4.19 \mathrm{E}-3 \mathrm{~m}$ \\
Minimum drag coefficient. $C_{D M I N}$ & 0.0025 \\
Hdry, Hflood & $0.05 \mathrm{~m}, 0.05 \mathrm{~m}$ \\
\hline
\end{tabular}

Table 3) and re-introduced later when the sea surface slope between the dried cell and the surrounding cells exceeds another threshold (Hflood, Table 3).

\section{Horizontal and vertical discretisation of the domain}

The numerical grid extends from $42.14^{\circ} \mathrm{N}$ to $42.25^{\circ} \mathrm{N}$ and from $8.92^{\circ} \mathrm{E}$ to $8.65^{\circ} \mathrm{E}$ (Fig. 1). It is oriented along the NE-SW axis of the Ría in order to provide a good representation of the large-scale bathymetric structure and hece of the flow in and out. Steeper horizontal variations are expected to develop more across the Ría than along the axis, and consequently the mesh is regular in the horizontal but has a grid size of $300 \mathrm{~m}$ in the direction across the Ría vs. 500 metres along the axis. This yields $42 \times 53$ grid boxes per horizontal level. Notice, however, that only about half of them are actually wet points.

The vertical discretization is done in the transformed $\sigma$-coordinate system where $\sigma$, the new vertical coordinate, is defined as:

$$
\sigma=\frac{z+h}{\zeta+h} \in[0,1]
$$

This transformation allows a continuous description of the bathymetry and hence a good representation of this important forcing factor, particularly for shallow water motions. Ten vertical levels are used in the $\sigma$ space. They are unevenly spaced to provide a finer resolution in which large vertical variations can be anticipated, i.e. at the surface and at the level of the possible thermocline. The distribution of $\Delta \sigma$ is, from bottom to top:

0.05/0.1/0.1/0.15/0.15/0.15/0.15/0.1/0.1/0.1/0.05/0.05
The real thickness $(\Delta z=H \Delta \sigma)$ of the different levels adapts to the local depth so that the discretization in the $\sigma$ coordinate system is valid for the whole domain. The thickness of the first level $\Delta \sigma$ at the bottom is taken small enough for the first U- and $\mathrm{V}$-points chosen to be in the logarithmic bottom boundary layer in the vast majority of the domain. The effect of the bottom boundary layer can then be easily and economically parameterized.

\section{Boundary conditions}

\section{Surface boundary conditions}

Boundary conditions at the air-sea interface are obtained by expressing those turbulent vertical fluxes of momentum, heat, etc. that are continuous except for boundary sources or sinks.

\section{Turbulent Kinetic energy flux}

The flux of turbulent kinetic energy at the surface boundary depends on wind intensity (Eq. 2, Table $4)$. Without wind, there is no input of $k$ through the surface. On the other hand, when the wind is blowing over the sea, breaking waves inject turbulence into the water column. We therefore preferred to prescribe the flux of turbulent kinetic energy instead of the surface value of $\mathrm{k}$, because this allows turbulent kinetic energy in the surface boundary layer to depend not only on wind conditions but also on what happens below.

\section{Momentum flux}

As the turbulent flux, the momentum flux in the atmospheric boundary layer depends on the wind forcing (Eq. 1, Table 4). Two different wind fields are used inside the domain to reproduce the differences in wind intensity and direction that are found inside and outside the Ría. The outer zone (from the open boundary to Home Cape, Fig. 1) is under a much greater oceanic influence and the winds blowing in this region are more intense, with a marked trend that could induce a long-term transport. In the innermost zone (from Mar Cape to the strait of Rande), the wind field is weaker and generally blowing along the main axis following the Ría's orography. Between the two zones, the model interpolates the two wind fields linearly. 
Momentum surface flux

$\tilde{v} \frac{\partial \mathbf{u}}{\partial \mathbf{z}}=C_{0}(1+0.1|\mathbf{W}|)|\mathbf{W}| \mathbf{W}$

Turbulent kinetic energy surface flux

$\tilde{v} \frac{\partial k}{\partial z}=3 C_{0} 10^{-3}|\mathbf{W}|^{3}$

Heat surface flux

$Q_{0}=\rho c_{p} \lambda \frac{\partial T}{\partial z}=I+C-I R-E$

$I=\left[3 \cdot 191+1 \cdot 115 \sin ^{2}[\pi(355-J) / 365]\right](50 \cdot 417-4 \cdot 474 N)$

$I R=\left(143-0.9 T_{S}-0.46 e_{a}\right)(1-0.1 N)$

$C=24.88(0.38+0.114|\mathbf{W}|)\left(T_{S}-T_{a}\right)$

$Q E=58.7 E$

$E=(0.26+0.077|\mathbf{W}|)\left(e_{s}-e_{z}\right)$

\section{Salinity surface flux}

There is no salinity flux at surface.

Freshwater open boundary discharge

$Q=0.007538+0.007889 A$

$A=(1-k) /\left(k-k^{365+1}\right) \sum_{n=1}^{365} P_{n} k^{n}$

Momentum bottom flux

$$
\begin{aligned}
\left|\tau_{b}\right| & =C_{D}\left|\mathbf{u}_{b}\right| \mathbf{u}_{b} \\
C_{D} & =\left(\left[\frac{\kappa}{\ln \left(z / z_{0}\right)}\right]^{2}, 0.0025\right)
\end{aligned}
$$

$C_{0}=0.6310^{-6}$

$\mathbf{W}=\left(\mathrm{u}_{0}, \mathrm{~V}_{0}\right)$ surface wind velocity in $\mathrm{m} \mathrm{s}^{-1}$

$\rho \quad$ Density of the water

$C p \quad$ Specific heat of the water

$Q$ o Surface heat flux

I Solar radiation $\left(\mathrm{w} \mathrm{m}^{-2}\right)$

$J \quad$ Day number starting 1 January

$N \quad$ Cloud cover in oktas

$I R \quad$ Infrared back radiation $\left(\mathrm{w} \mathrm{m}^{-2}\right)$

$T_{s} \quad$ Water surface temperature $\left({ }^{\circ} \mathrm{C}\right)$

$H_{a} \quad$ Relative humidity above the water surface

$e_{a} \quad$ Vapour pressure $2 \mathrm{~m}$ above the water surface $(\mathrm{mmHg})$

$e_{s} \quad$ Vapour pressure of water at the sea surface $(\mathrm{mmHg})$

C Heat by conduction

$T_{a} \quad$ Air temperature

$Q E \quad$ Heat lost by evaporation $\left(\mathrm{w} \mathrm{m}^{-2}\right)$

$E \quad$ Evaporation $\left(\mathrm{mm} \mathrm{day}^{-1}\right)$

Heat and salinity bottom fluxes

There are no heat and salinity fluxes at the bottom.

\section{Heat Flux}

The exchange of heat between the sea surface and the atmosphere is calculated by a set of well-known equations (i.e. Rosón et al., 1997), taking into account solar radiation, back radiation, conduction and evaporation (Eq. 3, Table 4). Incoming solar radiation is estimated using Mosby's formula (i.e. Dietrich et al., 1980), and the infrared back radiation component and the exchange of heat by conduction and heat lost by evaporation are evaluated by empirical equations (Otto, 1975). Air temperature, relative humidity and cloud cover are then required to compute the heat flux through the sur- face.

\section{Salinity}

We assume that the precipitation and evaporation balance each other. The salt flux through the surface is thus supposed to be zero.

\section{Open boundary conditions}

\section{$2 D$ Elevation boundary conditions}

At the open boundary with the shelf, $\mathrm{M}_{2}, \mathrm{~S}_{2}, \mathrm{~N}_{2}$ and $\mathrm{L}_{2}$, the most important tidal constituents for the 
Ría of Vigo are introduced through a radiation condition based on the theory of characteristics (Hedstrom, 1979; Røed and Cooper, 1987) and applied to the depth-integrated part of the signal. This procedure assumes that one Riemann variable (a combination of the total transport and free-surface elevation) is prescribed from information taken outside the domain, while the other Riemann variable is radiated outwards. The actual boundary value arises from the recombination of the two Riemann variables (Røed and Cooper, 1987). This procedure allows the forcing data from outside the domain to be incorporated, whilst avoiding spurious reflection on the boundary of perturbations generated inside the Ría.

\section{Temperature and salinity}

Salinity and temperature of inflowing shelf water are prescribed using observed data (real observations or climatological mean). At outflow boundaries, where water leaves the domain, the gradients of salinity and temperature normal to the boundary are supposed to vanish.

\section{Freshwater discharge}

The input of fresh water coming out of the Oitabén and Verdugo rivers is introduced by imposing this inflow on the top 5 meters of the water column at the inner open boundary. This freshwater runoff is estimated as a function of precipitation by using the equation given by Ríos et al. (1992) (Eq. 4, Table 4).

\section{Solid boundary conditions}

The coastline is a streamline and we must thus fix its impermeability. The component of the velocity vector normal to the coastline is set to zero at all depths. By virtue of their impermeability there are no advective or diffusive fluxes of any variable through solid boundaries.

As the bottom layer has been chosen to be in the logarithmic bottom boundary layer, the bottom stress can be parameterised using a quadratic expression of the bottom velocity, (Blumberg and Mellor, 1987) (Eq. 5 in Table 4). In those places where the bottom boundary layer is not well resolved (deepest areas), the drag coefficient is set to a minimum value $C_{D}=0.0025$ (c.f. Martín et al., 1993). A lateral friction is further introduced to take into an account the general slowing down of the stream induced by the unresolved coastal boundary layer.

\section{SIMULATION CONDITIONS}

The model was run to simulate the typical conditions that can be found at the end of the summer when changes between North and South winds are often taking place, defining two markedly different scenarios:

a) normal (or normal reinforced) estuarine circulation, with low salinity surface water flowing outwards and denser NACW water coming inwards in the bottom layer;

b) negative circulation due to intense south winds, with marked thermohaline fronts and near vertically homogeneous water conditions at the Ría's mouth.

In both situations, a constant river discharge of $13 \mathrm{~m}^{3} \mathrm{~s}^{-1}$ was assumed (the last ten years' mean value for the first fortnight of September). Rainfall used to calculate the river runoff was monitored by the Instituto Nacional de Meteorología at the meteorological station in Peinador airport, and corrected taking into account its altitude above sea level, (Ríos et al., 1992). Air temperature, relative humidity and cloud cover were provided by a meteorological station situated close to the Ría (Fig. 1).

The model started from rest with initial temperature and salinity $\left(16^{\circ} \mathrm{C}, 35.3\right.$ and $14^{\circ} \mathrm{C}, 35.7$ respectively) based on the observed hydrographic data taken at the isobath of $60 \mathrm{~m}$ during the September 1998 INCOCEANO 2 survey.

Temperature and salinity open boundary conditions were related to the observed hydrographic profiles measured at the South mouth of the Ría (Fig. 1) in different wind conditions during the INCOCEANO 2 survey. The same boundary conditions were imposed at both the southern and the northern mouth.

Before the results were collected, a 30 day spin-up was used under near negligible northerly wind to guarantee the dynamic adjustment of the flow field and the thermohaline structure. The resulting fields are characterised by a weak estuarine type circulation pattern with a residual current of about $0.04 \mathrm{~m} \mathrm{~s}^{-1}$.

In order to appraise the influence of different meteorological conditions on the hydrodynamics, two numerical experiments were then carried out using two types of wind forcing: (1) upwelling-favourable winds and (2) downwelling-favourable winds.

In the outer zone, the upwelling-favourable condition referred to a wind blowing southward $\left(350^{\circ}\right)$, while the downwelling-favourable situation brought 
up the wind blowing near northward $\left(190^{\circ}\right)$. The magnitude of the wind was set to $7 \mathrm{~m} \mathrm{~s}^{-1}$ in both cases, which correspond approximately to the mean of intense wind periods taking place during August and September. In the inner zone, the wind speed is taken to be half of the value on the shelf, while the direction reflects the channelling effect of the Ría with southwestward winds $\left(40^{\circ}\right)$ in an upwellingfavourable situation and northeastward winds $\left(220^{\circ}\right)$ in an downwelling-favourable situation.

Both simulations have been performed with the same fluctuations in the solar radiation, cloud cover, relative humidity and fresh water inputs, which are representative of the natural variability observed in the data sets during the first fortnight of September.

\section{RESULTS AND DISCUSSION}

\section{Upwelling-favourable wind scenario}

\section{Current field}

After a period of 5 days with upwelling favourable winds (a typical periodicity for the wind variations in September (Figueiras et al., 1994), the current field, and accordingly the temperature and salinity fields, were significantly altered. The low salinity water was pushed away out of the Ría by the offshore surface Ekman-transport. The deep saltier and denser waters flowed into the Ría along the bottom. The result was a general pattern of residual circulation in two layers that is typical of a positive estuarine circulation and has been described previously by several authors (Mouriño et al., 1984; Blanton et al., 1984; Prego and Fraga, 1992) (Fig. 2).

At the surface, the wind induced an out-going residual current that fluctuated around $0.13 \pm 0.04$ $\mathrm{m} \mathrm{s}^{-1}$ in the surface layer and progressively diminished to reach zero at the level of the thermocline, (Fig. 3f). Taboada et al. (1998) gave smaller outgoing velocities, probably due to the lack of an explicit wind forcing mechanism in their model. In fact, surface velocities estimated from real hydrological data and taking into account the wind forcing showed an average surface velocity of $0.13 \mathrm{~m} \mathrm{~s}^{-1}$ during a September upwelling event (Alvarez-Salgado et al., 1998). Also, a near-surface current meter record deployed at $2.7 \mathrm{~m}$ depth from 11 to $27 \mathrm{Sep}-$ tember 1990 in the middle of the Ría de Vigo (Figueiras et al., 1994) showed a persistent outflow of water (average of $0.09 \mathrm{~m} \mathrm{~s}^{-1}$ ) to the southwest dur-
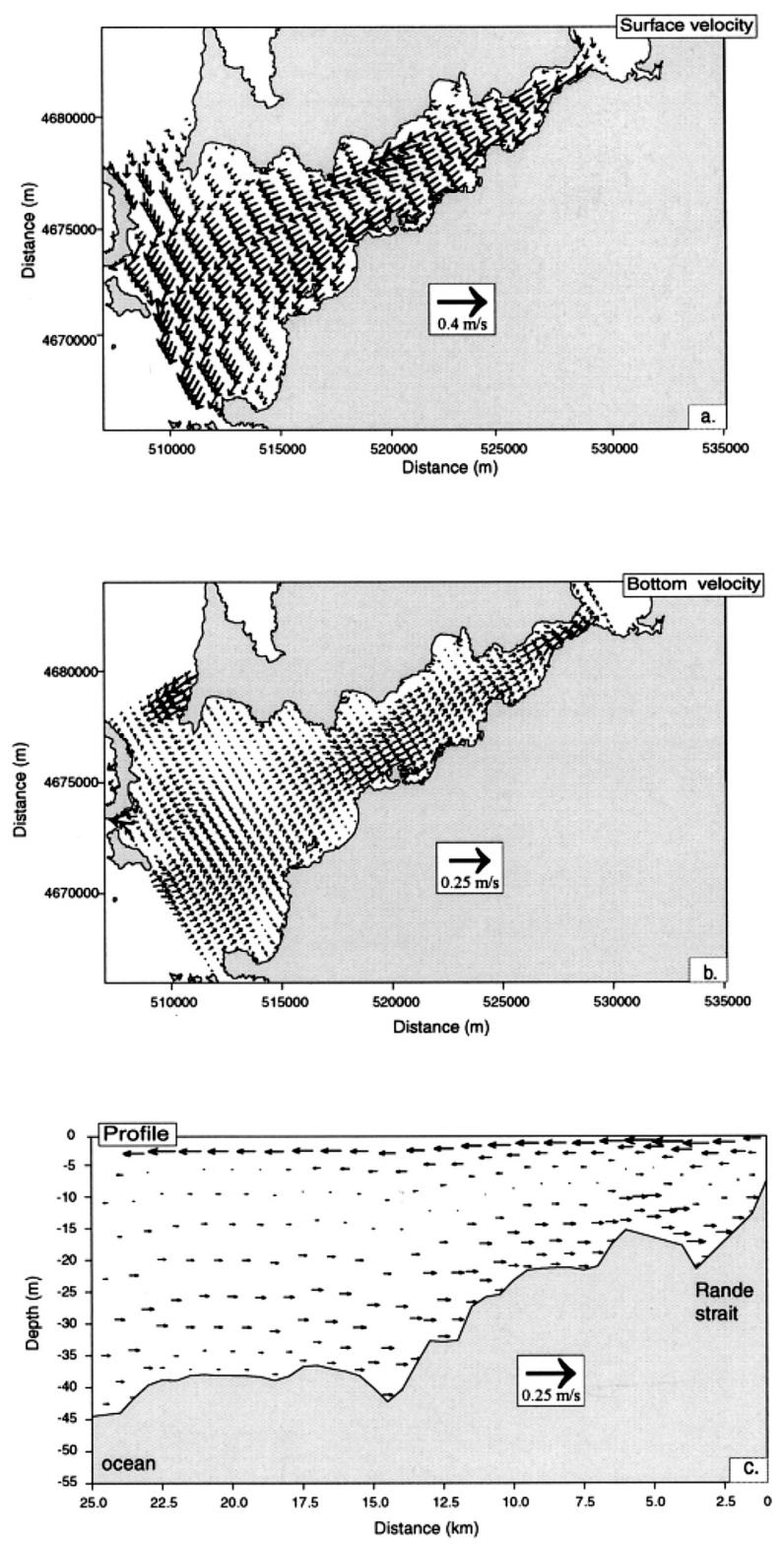

FIG. 2. - Residual circulation during upwelling-favourable wind (a) in the surface layer and (b) in the bottom layer. (c) Vertical profile of the residual velocity component $u$ plotted along the main axis of the Ría.

ing an upwelling situation.

The most striking feature of the surface circulation was the moderately strong (around $0.15 \mathrm{~m} \mathrm{~s}^{-1}$ ) current leaving the Ría at its Southwest mouth, in contrast with a weak $\left(0.03 \mathrm{~m} \mathrm{~s}^{-1}\right)$ stream entering through the northern mouth. Neither the box model of Prego et al. (1992) nor the 3-D hydrodynamical model of Taboada et al. (1998) reproduced this peculiarity. The bathymetry and differences in orientation of the two mouths with respect to wind direction could influence in the general circulation: when quite strong northerly winds are blowing, the 

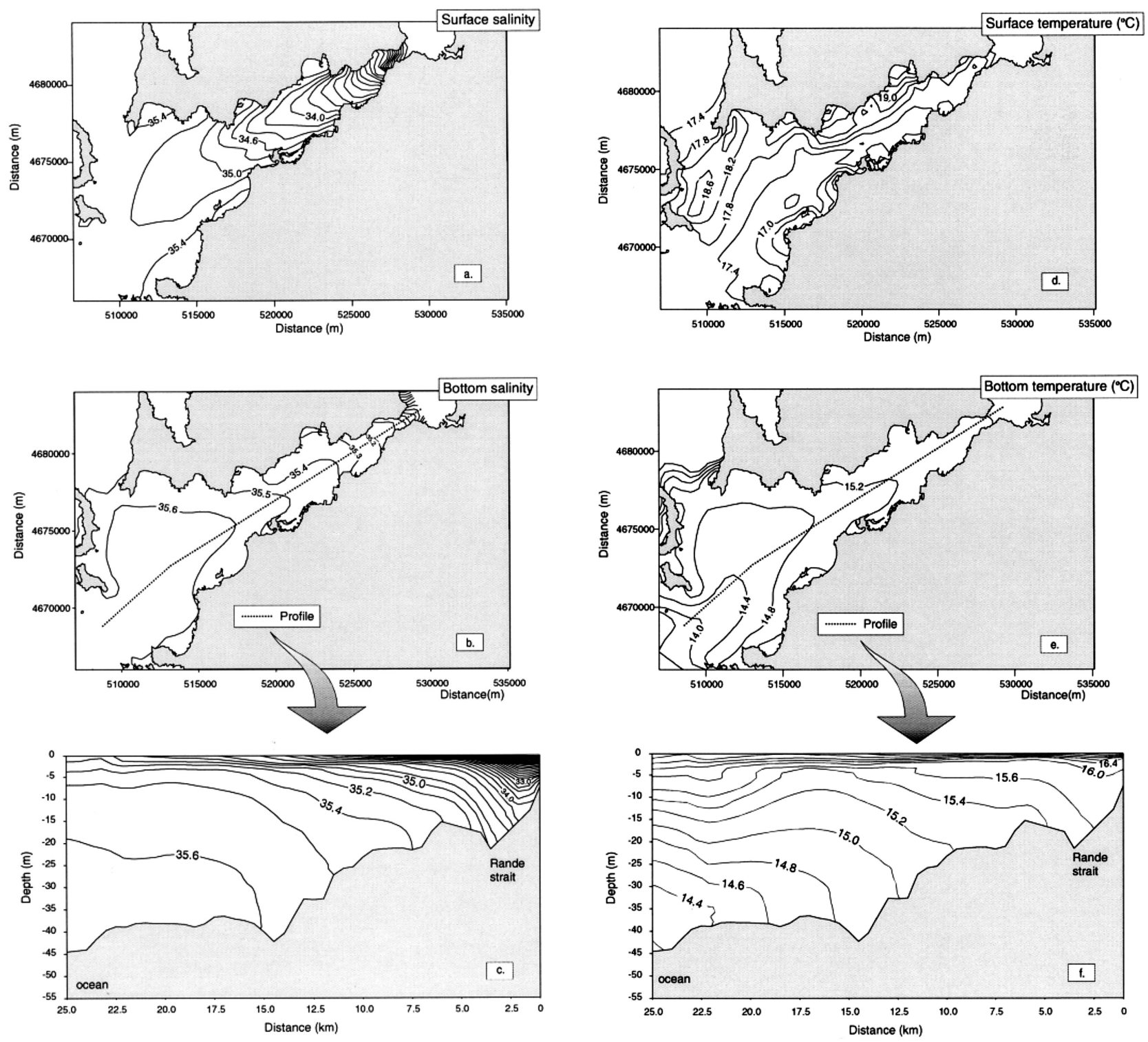

FIG. 3. - Salinity and temperature distribution after 5 days of a moderately strong ( $\left.7 \mathrm{~m} \mathrm{~s}^{-1}\right)$ northerly wind. (a) surface salinity, (b) bottom salinity, (c) vertical salinity profile depicted in the dotted line in (b), (d) surface temperature, (e) bottom temperature, and (f) vertical salinity profile as shown in the dotted line in (e).

southwestern mouth (which is $5 \mathrm{~km}$ wide and $67 \mathrm{~m}$ deep) forms a free open boundary, where a clear outgoing signal could be developed by means of the "wind-induced" transport. On the other hand, in the smaller northern mouth (only $2.5 \mathrm{~km}$ wide and $23 \mathrm{~m}$ deep) the wind-induced surface transport coming from the continental shelf blocks out the water flowing outwards and causes it to turn to the wider and deeper southern mouth. Nevertheless, some unrealistic values are detected at the northern mouth, probably caused by still unresolved boundary problems.

Below the thermocline, the wind forcing had nearly no influence on the general circulation and a compensatory inshore flux was established below the zero velocity level, as is shown in Fig. $2 b$. The incoming saltier water penetrated through the southwestern mouth and forked into two different currents: one flowing in the direction of the main axis of the Ría, and one turning to the right and describing a cyclonic gyro (already cited by Fraga and Prego, 1989) and probably induced by the presence of the Cíes Islands.

In the bottom layer, the magnitude of the velocity ranged from $0.01 \mathrm{~m} \mathrm{~s}^{-1}$ (where there was no influence of the incoming current) to $0.05 \mathrm{~m} \mathrm{~s}^{-1}$ in the rest of the domain. Both the bottom circulation pattern and the average velocities were in close agreement with those given by the model of Taboada et al. 
(1998). Some observational data support both model results, since Álvarez-Salgado et al. (1998) found depth-averaged residual velocities (4-26 m) of 0.045 $\mathrm{m} \mathrm{s}^{-1}$ at the middle of the Ría's main axis.

Over the studied period, the transition zone between opposite flows (level of non-horizontal motion) reflected the bathymetry (Fig. 2c). It uplifted inward from $8.5 \mathrm{~m}$ at the open boundary to $4.5 \mathrm{~m}$ at the inner part, getting deeper in the middle $(14 \mathrm{~m})$. This near-zero velocity level closely follows the thermocline depth (Fig. 3c) and agrees reasonably with the one simulated by the model of Taboada et al. (1998) (7.6 $\mathrm{m}$ in the inner part to $8.9 \mathrm{~m}$ in the outer zone) or that of Prego et al. (1992) (5.4 m in the inner box and $9.3 \mathrm{~m}$ in the outer box).

Moreover, Álvarez-Salgado et al. (1998), and Prego and Fraga (1992) found similar results in September observed data. Both of them localised the non-motion level (assuming it as the pycnocline depth) at a depth ranging from $4 \mathrm{~m}$ to $6 \mathrm{~m}$ during different upwelling events.

To sum up, a north wind episode results in a single circulation cell with a weak upwelling in the middle part of the Ría limited by the strong stratification, a narrow and strong offshore flow at the surface, and a compensatory wider and weaker onshore flow in the deep region.

\section{Temperature and salinity fields}

There were appreciable quantitative differences in the salinity and temperature surface layer between one side of the Ría and the other. Low salinity values $(<32)$ were observed in the vicinity of San Simón bay, where rivers discharge. This fresh water flows out preferably along the north shore. Warm water $\left(>18^{\circ} \mathrm{C}\right)$ followed this low saline stream along the north shore until Home Cape and then turned to the southern mouth. On the other side, at the south shore, saltier and colder water $\left(>35.4,<16.60^{\circ} \mathrm{C}\right)$ uplifted from deeper levels and rose to the surface (Figs. 3a and 3d).

In the bottom layer, lower salinities $(<35.0)$ and higher temperatures $\left(>15.40^{\circ} \mathrm{C}\right)$ were located close to the Rande Strait, while saltier and colder waters $\left(>35.6,<14.0^{\circ} \mathrm{C}\right)$ penetrated through the southern mouth and flowed into the Ría close to the south shore (Figs. $3 b$ and 3e).

The upwelling situation was evident in the thermal structure through the uplift of the isotherms and the compression of the temperature gradient in the upper $5 \mathrm{~m}$ (Fig. 3f). Although relatively high temperatures
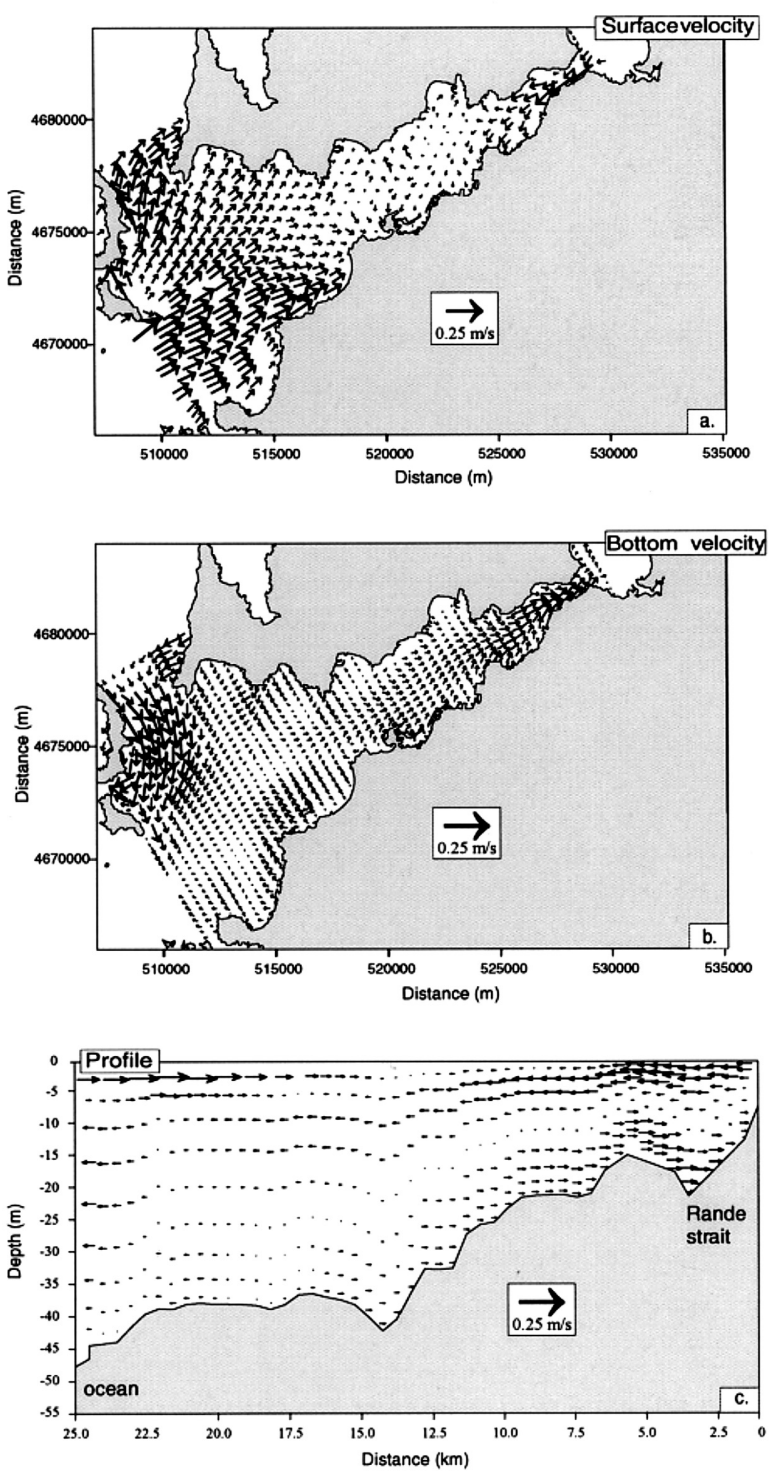

FIG. 4. - Residual circulation during downwelling-favourable wind (a) in the surface layer and (b) in the bottom layer. (c) Vertical profile of the residual velocity component $u$ plotted along the main axis of the Ría.

$\left(>14^{\circ} \mathrm{C}\right)$ have been measured in the bottom layer during upwelling events and were justified by the rapid mixing with other water bodies when cold shelf water enters the Ría (Álvarez-Salgado, 1996), it is more usual to find colder waters $\left(<13.5^{\circ} \mathrm{C}\right)$. The predicted bottom temperatures, which ranged from $14.4^{\circ} \mathrm{C}$ to $15.5^{\circ} \mathrm{C}$ (Fig. 3f), were slightly higher than those expected from observations. The differences may be explained by the fact that the domain did not include a greater percentage of the adjacent shelf and the entrance of shelf cold water caused by an upwelling event off the Galician coast was possible underestimated. Nevertheless, the temperature and salinity model results compared reasonably well (especially in the upper layer) with numerous observational data 
(e.g. Figueiras et al., 1994; Egleé, 1996).

Therefore, the combined effect of temperature and salinity resulted in the development of a strong stratification that led to a positive circulation. The thermocline and the halocline depth coincided with the non-motion level, ranging from $3.5 \mathrm{~m}$ in the inner part to $8 \mathrm{~m}$ in the outer part.

\section{Downwelling-favourable winds scenario}

\section{Current field}

During a downwelling situation, south winds advected relatively dense oceanic surface water into the Ría, generating a major onshore transport. Con-
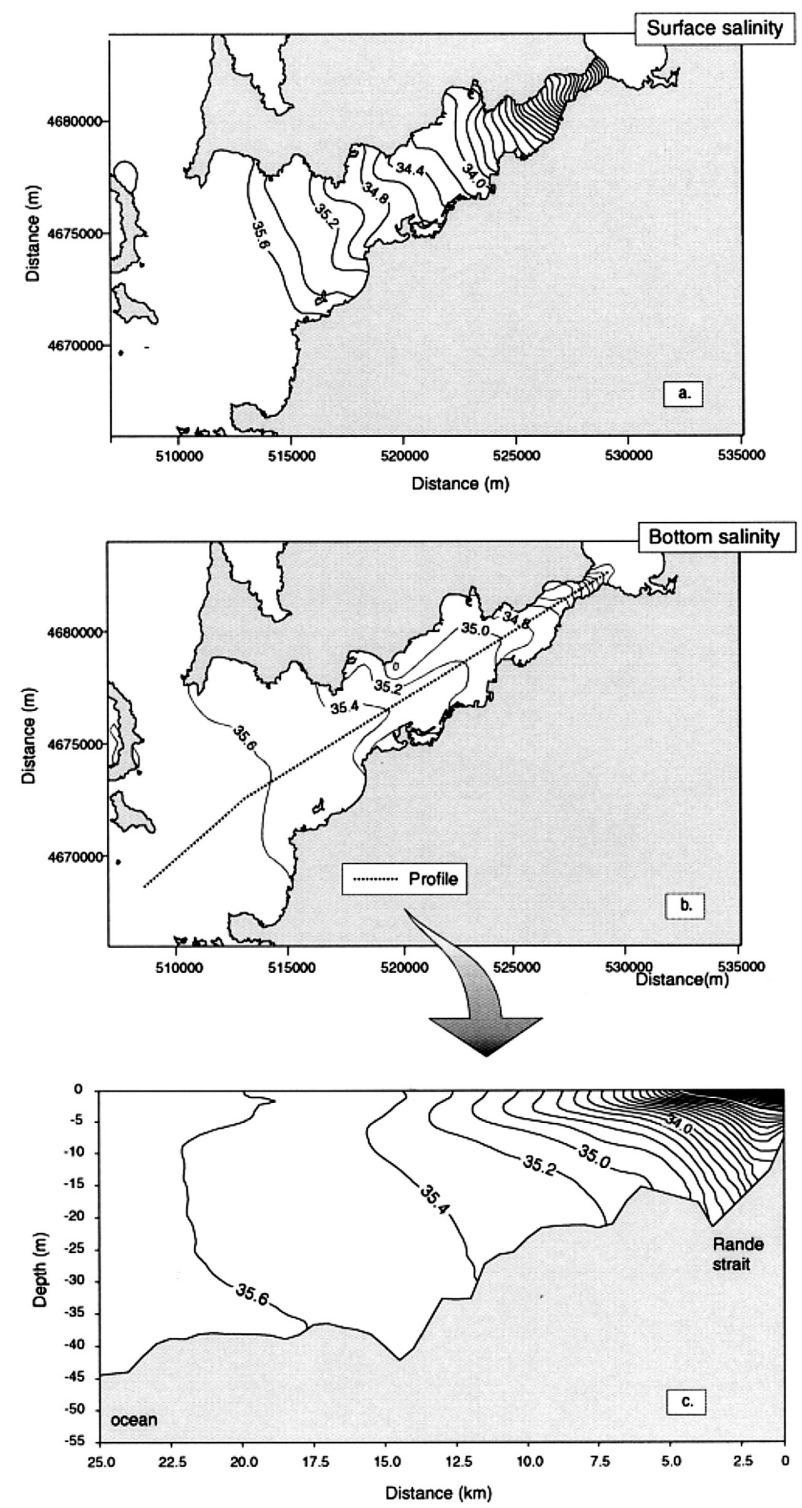

sequently, surface waters from the inner part of the Ría were strongly mixed with shelf ones, leading to a convergence front $20 \mathrm{~km}$ off the Rande Strait, as isotherm and isohaline deepening indicates (Figs. 4 and 5), and dividing the Ría into two different circulation cells with different thermohaline properties.

In the inner and middle part of the domain, the spatial structure of the residual circulation was similar to that generated by northerly winds. This area maintained a positive estuarine circulation, although the magnitude of the velocities had diminished strongly due to the blocking of the surface outflow at the front zone; the residual velocity was less than $0.03 \mathrm{~m} \mathrm{~s}^{-1}$ throughout the column, increasing the water flushing time (9.5 days) inside the Ría. The
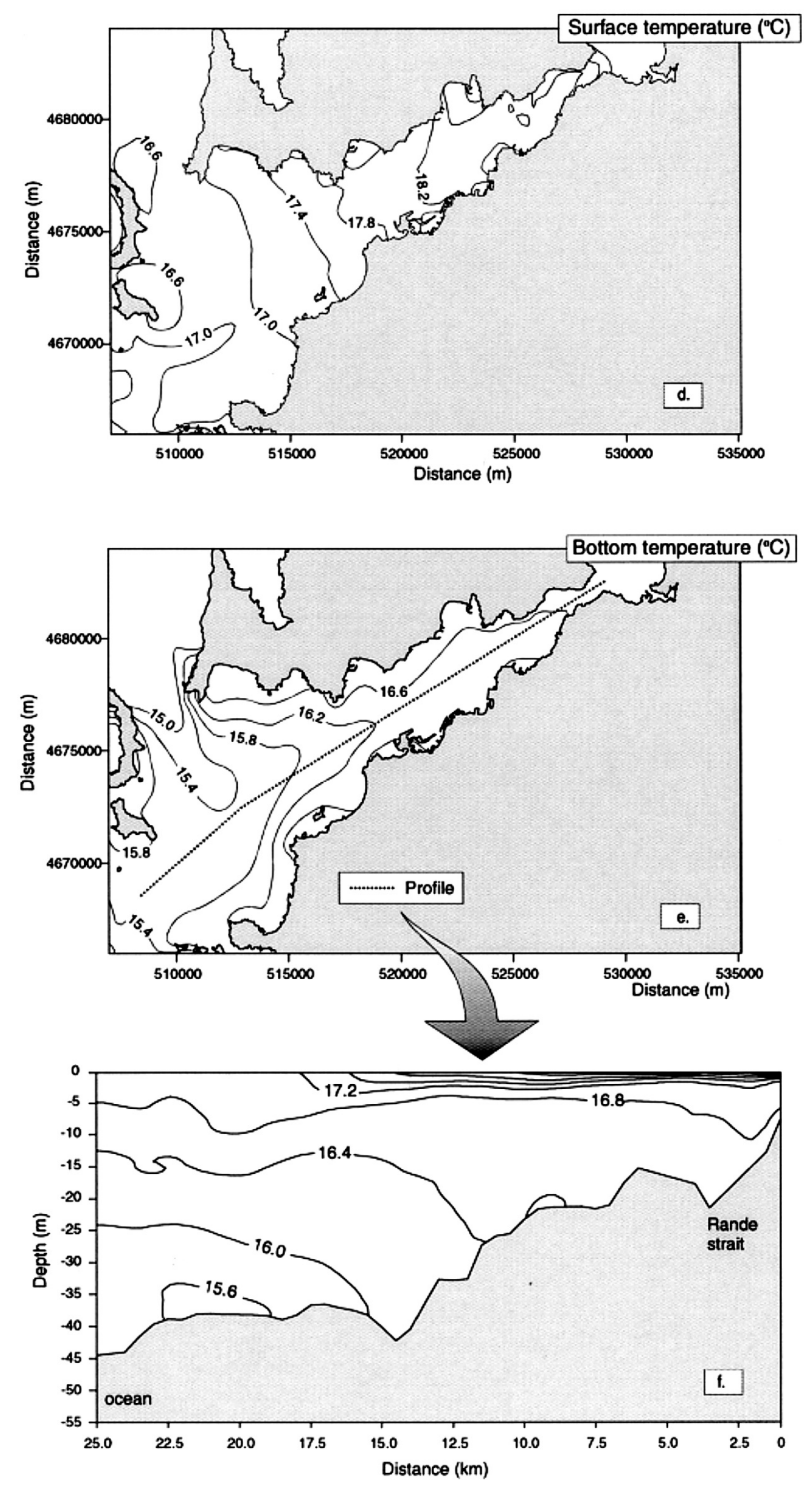

FIG. 5. - Salinity and temperature distribution after 5 days of a moderately strong ( $\left.7 \mathrm{~m} \mathrm{~s}^{-1}\right)$ southerly wind. (a) surface salinity, (b) bottom salinity, (c) vertical salinity profile depicted in the dotted line in (b), (d) surface temperature, (e) bottom temperature, and (f) vertical salinity profile as shown in the dotted line in (e). 
position of the non-motion level in this zone was deeper than the zero velocity level generated by Nnorth winds, uplifting inward from $30 \mathrm{~m}$ at the frontal zone to about $10 \mathrm{~m}$ close to San Simon Bay. The result was the development of a semi-closed circulation pattern (Fig. 4c).

Nearer to the shelf, the associated residual currents form a characteristic inverse circulation pattern, with a strong water inflow at the surface through the southern mouth $\left(0.14 \pm 0.02 \mathrm{~m} \mathrm{~s}^{-1}\right)$ and a weaker and wider countercurrent $\left(0.02 \pm 0.02 \mathrm{~m} \mathrm{~s}^{-1}\right)$ between $10 \mathrm{~m}$ and $30 \mathrm{~m}$ depth. A similar circulation pattern has been reported with South wind episodes (Figueiras et al., 1994; Tilstone et al., 1994; Fraga and Prego, 1989; Castro et al., 1994).

Few real and no modelled velocity data were available to compare model results in a downwelling situation. Using a surface current meter, Figueiras et al. (1994) recorded a reversed net residual flow into the Ría to the Northeast, in accordance with the residual velocity fields of the model. The magnitude of the velocity ranged between $0.11 \mathrm{~m} \mathrm{~s}^{-1}$ and 0.01 $\mathrm{m} \mathrm{s}^{-1}$ (with a mean of $0.05 \mathrm{~m} \mathrm{~s}^{-1}$ ).

\section{Temperature and salinity field}

The downwelling-favourable thermohaline distribution differed markedly from the upwellingfavourable one. South wind enhanced the turbulent vertical mixing and led to a nearly uniform vertical structure of thermohaline properties.

In the surface layer (Figs. 5a and 5d), the lowest salinity and highest temperature values $\left(32\right.$ and $\left.19^{\circ} \mathrm{C}\right)$ corresponding to bodies of less saline water due to river runoff were found in the innermost area, where river water was kept back by the shelf influx. The saltiest and coldest waters $\left(35.6\right.$ and $\left.17.0^{\circ} \mathrm{C}\right)$ were clearly present at the most external part of the Ría.

At the bottom, the salinity field remained quite invariable in comparison with the surface one, and somewhat saltier (33.0) at the head of the Ría (Fig. $5 \mathrm{c})$. Indeed, the halocline was not so developed as with north winds (Fig. 3c).

Changes in the vertical temperature and salinity distribution in different wind conditions were evident and in close accordance with observations (Figueiras et al., 1994). During upwellingfavourable winds the isotherm uplift and warm water was confined near the surface. North wind tended to speed up the interchange with the shelf, diminishing the water flushing time inside the Ría (4.5 days) and therefore reducing the warming of the upper layer. In contrast, during downwellingfavourable winds the colder water observed in the initial conditions moved out towards the ocean, leaving a more homogeneous water column with temperatures of $>15.8{ }^{\circ} \mathrm{C}$. Moreover, a general warming took place due the increasing of the water flushing time (9.5 days) inside the Ría.

\section{CONCLUSIONS}

The use of a mathematical 3-D model to investigate the hydrodynamic processes in the Ría de Vigo provides a considerable help in the description of observations. Observed features can be explained from the point of view of their dynamics and their links with various processes and forcing factors.

This model pushes forwards the study of the hydrodynamic structure in the Ría de Vigo with different meteorological forcing, inducing noticeable changes in the thermohaline distribution and the residual circulation pattern at a time scale of the order of five days. This is an important advance in comparison with earlier model attempts (e.g. Taboada).

A downwelling situation has never been simulated using a 3-D model. Winds with a strong north component tend to produce a positive estuarine circulation, while powerful southerly winds arise in an atypical reversal circulation pattern, which reduces the outgoing velocities inside the Ría. These results are supported by the fact that salinity, temperature and velocity fields are in good agreement with the experimental data.

\section{ACKNOWLEDGEMENTS}

A fellowship from the Xunta de Galicia allowed S. Torres-López to carry out this work. Meteorological data were kindly supplied by the Instituto de Investigacions Mariñas and by the Instituto Español de Oceanografía de Vigo. We also thank the "Comisión Interministerial de Ciencia y Tecnología” (CICYT), which financed the survey, INCOCEANO2 included in the project MAR95-1901-C03-02. Finally, the authors also wish to thank V. Rico for his invaluable help in the design of figures.

\section{REFERENCES}

Alejo, I. - 1994. Estudio dinámico y sedimentario de la Bahía de 
Bayona. Ph. D. Thesis, Univ. Vigo.

Arakawa, A. and V. Lamb. - 1977. Computational design of the basic dynamical processes of the UCLA general circulation model. Meths. Comput. Phys., 17: 173-265.

Alvarez-Salgado, X.A., G. Rosón, F.F. Pérez, F.G. Figueiras and Y. Pazos. - 1996. Nitrogen cycling in an estuarine upwelling system, the Ría de Arousa (NW Spain). I. Short-time-scale patterns of hydrodynamic and biogeochemical circulation. Mar. Ecol. Prog. Ser., 135: 259-273.

Alvarez-Salgado, X.A., F.G. Figueiras, M.L. Villarino and Y. Pazos. - 1998. Hydrodynamic and chemical conditions during onset of a red-tide assemblage in an estuarine upwelling ecosystem. Mar. Biol., 130: 509-519.

Bakun, A. and C.S. Nelson. - 1991. The seasonal cycle of windstress curl in subtropical eastern boundary current regions. $J$. Phys. Oceanogr., 21: 1815-1834.

Blanton, J.O., L.P. Atkinson, Fernández de Castillejo and A.L. Montero. - 1984. Coastal upwelling off the Rías bajas, Galicia, Northwest Spain I: Hydrographic studies. Rapp. P.-v. Reun. Cons. Int. Explor. Mer., 183: 79-90.

Beckers, J.M. - 1991. Application of the GHER 3D general circulation model to the Western Mediterranean. J. Mar. Syst., 1: 315-332.

Beckers, J.M. and E. Deleersnijder. - 1993. Stability of a FBCTS scheme applied to the propagation of shallow-water inertiagravity waves on various space grids. J. Comput. Phys., 108: 95-104.

Beckers, P.M. and R.J. Neves. - 1985. A semi-implicit tidal model of the North European Continental Shelf. Appl. Math. Model., 9: $395-402$.

Castro, C.G., F.F. Pérez, X.A. Álvarez-Salgado, G. Rosón, and A.F. Ríos. - 1994. Hydrographic conditions associated with the relaxation of an upwelling event off the Galician coast (NW Spain). J. Geo. Res., 99(C3): 5135-5147.

Delhez E.J.M. and G. Martin. - 1992. Preliminary results of 3D baroclinic numerical models of the mesoscale and macroscale circulation on the North-West European Continental Shelf. $J$. Mar. Syst., 3(4-5): 423-440.

Delhez, E.J.M., M. Grégoire, J.C.J. Nihoul and J.M. Beckers. 1999. Dissection of the GHER turbulence closure scheme. $J$. Mar. Syst., 21:379-397.

Dietrich, G., K. Kalle, W. Krauss and G. Siedler. - 1980. General Oceanography. An Introduction. Second edition. J. Wiley \& Sons, New York.

Doval, M.D., X.A. Álvarez-Salgado and F.F. Perez. - 1997. Dissolved organic matter in a temperate embayment affected by coastal upwelling. Mar. Ecol. Prog. Ser., 157: 21-37.

Eglée, G.F. - 1996. Acoplamiento dinámico entre las poblaciones de microplancton y la circulación en la Ría de Vigo (NO España). Ph. D. Thesis, Univ. Vigo.

Fraga, F. and R. Prego. - 1989. Condiciones hidrográficas previas a la purga de mar. Cuad. Area Ciencias del mar. Semin. Estud. Galegos, 4: 21-44.

Fraga, S. - 1996. Ondas internas en la plataforma frente a la Ría de Vigo y posibles consecuencias ecologicas. Sci. Mar., 60: 543-547.

Figueiras, F.G., K.J. Jones, A.M. Mosquera, X.A. Álvarez-Salgado, A. Edwards and N. MacDougall. - 1994. Red tide assemblage formation in an estuarine upwelling ecosystem: Ría de Vigo. $J$. Plankton Res., 16(7): 857-878.

Gomez-Gesteira, M., P. Montero, R. Prego, J.J. Taboada, P. Leitao, M. Ruiz-Villarreal, R. Neves and V. Perez-Villar. - 1999. A two-dimensional particle tracking model for pollution dispersion in A Coruña and Vigo Rías (NW Spain). Oceanol. Acta, 22(2): 167-177.

Gregoire, M., J.M. Beckers, J.C.J. Nihoul and E. Stanev. - 1998. Reconnaissance of the main Black Sea's ecohydrodynamics by means of a 3D interdisciplinary model. J. Mar. Syst., 16(1-2):
85-106.

Hedstrom, G.W. - 1979. Non reflecting boundary conditions for non linear hyperbolic systems. J. Comput. Phys., 30: 222-237.

James I.D. - 1986. A front resolving sigma coordinate sea model with a simple hybrid advection scheme. Appl. Math. Model., 10: 87-92.

López-Jurado J.L. - 1985. Notas climatologicas e hidrologicas de las Rías bajas. Infs. Tec. Inst. Esp. Oceanog., 23: 1-13.

Margalef, R. and B. Andreu. - 1958. Componente vertical de los movimientos del agua en la Ría de Vigo y su posible relación con la entrada de sardina. Invest. Pesq., 11: 67-100.

Martin, G.P. and E.J. Delhez. - 1994. 3D turbulence field on the North-Western European Continental Shelf. Telllus, 46(A): 98-112.

Mouriño, C., F. Fraga and F. Fernández-Pérez. - 1984. Hidrografia de la Ría de Vigo, 1979-80. In: Cuadernos da Area de Ciencias Mariñas Vol.1. Actas do primerior Seminario de ciencias do Mar: As Rías galegas. Edicios do Castro, pp.91-103, La Coruña.

Nihoul, J.C.J. - 1984. A 3D general marine circulation model in a remote sensing perspective. Annales Geophysicae, 2(4): $433-442$.

Nihoul, J.C.J., E. Deleersnijder and S. Djenidi. - 1989. Modelling the general circulation of shelf seas by 3D $k-\varepsilon$ models. EarthScience Rev., 26: 163-189.

Nogueira, E., F.F. Pérez and A.F. Ríos. - 1997a. Seasonal patterns and long-term trends in an estuarine upwelling ecosystem (Ría de Vigo, NW Spain). Estuar. Coast. Shelf Sci., 44: 285-300.

Nogueira, E., F.F. Pérez and A.F. Ríos. - 1997b. Modelling thermohaline properties in an estuarine upwelling ecosystem (Ría de Vigo, NW Spain) using Box-Jenkins transfer function models. Estuar. Coast. Shelf Sci., 44: 685-702.

Nogueira, E., F.F. Pérez and A.F. Ríos. - 1998. Modelling nutrients and chorophyll time course in an estuarine upwelling ecosystem (Ría de Vigo, NW Spain) using Box-Jenkins tranfer function models. Estuar. Coast. Shelf Sci., 46: 267-286.

Otto, L. - 1975. Oceanography of the Ría de Arosa (NW Spain). Konik, Meteor International Medelingen en Verlan., 96, 210 pp.

Prego, R. - 1988. El nitrógeno orgánico en la Ría de Vigo: distribución y relación con el nitrógeno inorgánico en verano. In: IV Seminario de Quimica Marina, 37-45.

Prego R. and F. Fraga. - 1992. A simple model to calculate the residual flows in a Spanish Ría. Hydrographic consequences in the Ría de Vigo. Estuar. Coast. Shelf Sci., 34: 603-615.

Ríos, A.F., M.A. Nombela, F.F. Perez, G. Rosón and F. Fraga. 1992. Calculation of runoff to an estuary. Ría de Vigo. Sci. Mar., 56: 29-33.

Rosón,G., F.F. Perez, X.A. Álvarez-Salgado and F.G. Figueiras. 1995. Variation of both thermohaline and chemical properties in an estuarine upwelling ecosystem: Ría de Arousa. I Time evolution. Estuar. Coast. Shelf Sci., 41: 195-213.

Rosón, G., X.A. Álvarez-Salgado and F.F. Pérez. - 1997. A nonstationary box model to determine residual fluxes in a partially mixed estuary, based on both thermohaline properties: Application to the ría de Arousa (NW Spain). Estuar. Coast. Shelf Sci., 44: $249-262$

Røed L.P. and C.K. Cooper. - 1987. A study of various open boundary conditions for wind-forced barotropic numerical ocean models. In: J.C.J. Nihoul and B. Jamart (eds.), Threedimensional models of marine and estuarine dynamics, $\mathrm{pp}$. 305-336. Elsevier.

Taboada, J.J., R. Prego, M. Ruiz-Villarreal, M. Gómez-Gesteira, P. Montero, A.P. Santos and V. Pérez-Villar. - 1998. Evaluation of the seasonal variations in the residual circulation in the Ría de Vigo (NW Spain) by means of a 3D baroclinic model. Estuar. Coast. Shelf Sci., 47: 661-670.

Tilstone, G.H., F.G. Figueiras and F. Fraga. - 1994. Upwelling- 
